American Journal of Environmental Sciences 5 (3): 420-426, 2009

ISSN 1553-345X

(C) 2009 Science Publications

\title{
Reducing Ammonia Loss from Urea by Mixing with Humic and Fulvic Acids Isolated from Coal
}

\author{
${ }^{1}$ Ameera Abdul Reeza, ${ }^{1}$ Osumanu Haruna Ahmed, \\ ${ }^{2}$ Nik Muhamad Nik Ab. Majid and ${ }^{3}$ Mohamadu Boyie Jalloh \\ ${ }^{1}$ Department of Crop Science, Faculty of Agriculture and Food Science, \\ University Putra Malaysia Bintulu Campus, Sarawak, 97008 Bintulu, Sarawak, Malaysia \\ ${ }^{2}$ Department of Forestry, Faculty of Agriculture and Food Sciences, \\ University Putra Malaysia, Bintulu Campus, Sarawak, 97008 Bintulu, Sarawak, Malaysia \\ ${ }^{3}$ School of Sustainable Agriculture, University Malaysia Sabah, \\ Locked Bag 2073, 88999 Kota Kinabalu, Sabah, Malaysia
}

\begin{abstract}
Problem statement: Ammonia volatilization is a major pathway for nitrogen loss from surface applied urea. While all top-dressed ammonia and ammonium based $\mathrm{N}$ fertilizers can volatilize, the potential loss is greatest with urea and fluids containing urea. As much as $20-50 \%$ of $\mathrm{N}$ applied to soils is lost through volatilization alone. Thus, the objective of this laboratory study was to reduce ammonia loss from urea via mixing with humic and fulvic acids isolated from coal. Approach: This study compared four different types of treatments which were urea without additives (T1), urea with humic acid-powdered form (T2), urea with fulvic acid-liquid form (T3) and urea with humic and fulvic acids-liquid form (T4). Comparisons were made based on ammonia loss, soil $\mathrm{NH}_{4}$ and $\mathrm{NO}_{3}{ }^{-}$contents as well as exchangeable cations in the treated soils. Soil samples from typic paleudults (Bekenu series) were used. Humic substances were isolated using standard procedures. Daily ammonia loss from soil was measured using a modified closed-dynamic air flow system method. Results: All of the treatments with humic substances significantly reduced ammonia loss ranging between 13 and $25 \%$ compared to urea alone. The treatment with both humic and fulvic acids (T4) showed pronounced ammonia loss reduction. All treatments with humic substances significantly increased $\mathrm{NH}_{4}{ }^{+}$and $\mathrm{NO}_{3}{ }^{-}$content in soil samples compared to urea alone except for treatment having humic acid alone (T2). Treatments with fulvic acid (T3 and T4) also showed significant increase in exchangeable $\mathrm{K}^{+}$and $\mathrm{Na}^{+}$compared to urea alone. The increase in the formation of $\mathrm{NH}_{4}{ }^{+}$over $\mathrm{NH}_{3}$, soil exchangeable cations and temporary reduction of soil $\mathrm{pH}$ may had retarded urea hydrolysis in the immediate vicinity of the fertilizer. Conclusion: Surface applied urea fertilizer efficiency could be increased if applied together with humic and fulvic acids.
\end{abstract}

Key words: Ammonia loss, urea, humic and fulvic acids, ammonium, nitrate and exchangeable cations

\section{INTRODUCTION}

The use of urea accounts for approximately $51 \%$ of the world's agricultural $\mathrm{N}$ consumption ${ }^{[1]}$. Widespread acceptance of urea was delayed in part due to its greater potential for $\mathrm{N}$ loss via ammonia volatilization. While all top-dressed ammonia and ammonium-based $\mathrm{N}$ fertilizers can volatilize, the potential is greatest with urea and fluids containing urea with as much as $20-50 \%$ of $\mathrm{N}$ applied to soil lost through volatilization alone. According to Bundy ${ }^{[2]}$, ammonia loss from ureafertilized soils usually occurs when urea-containing fertilizer is surface-applied and not incorporated. The amount of nitrogen lost through ammonia volatilization from surface applied urea is greatly affected by soil and climatic conditions. Thus, understanding the factors that influence volatilization will enable urea users to select management practices that minimize volatilization. This will increase the quantity of applied $\mathrm{N}$ recovered by the crop as well as improving production efficiency and reduce potential impacts of $\mathrm{N}$ use on the environment ${ }^{[3]}$.

To manage the risk of $\mathrm{NH}_{3}$ loss, several studies have been done to alleviate the problem. Research has shown that one of the ways to enhance plant $\mathrm{N}$ use

Corresponding Author: Osumanu Haruna Ahmed, Department of Crop Science, Faculty of Agriculture and Food Sciences, University Putra Malaysia Bintulu Campus, Sarawak, Malaysia, Tel: +6086855406 Fax: +608685415 
efficiency of urea and TSP mixtures is to mix them with humic acids $^{[4]}$ as these acids are known to have chemical properties such as high total acidity (CEC) useful in retaining $\mathrm{NH}_{4}{ }^{+}$as well as aiding in ammonia volatilization reduction ${ }^{[5]}$. Humic substances are the most chemically active compounds in soils with cation and anion exchange capacities far exceeding those of clays $^{[6]}$ and having various capabilities beneficial to agricultural soils.

The major sources of humic substances generally can be found in coal as it contains the largest amount of humified substances particularly, HA (humic acid), FA (fulvic acid) and humin. Lobartini et al. ${ }^{[7]}$ reported that commercial grade lignite from North Dakota compose substantial amount of HA $(99.0 \%)$ in contrast to that of FA (1\%). Lignite or leonardite samples were also noted, on average, to compose $99.5 \mathrm{HA}$ and $0.5 \%$ of $\mathrm{FA}^{[8,9]}$.

Although much studies have been done regarding $\mathrm{HA}$ and its role in alleviating agricultural problems, much is yet to be known on FA and their role in ammonia loss reduction. Hence, this study aimed to investigate the effect of HA and FA isolated from coal in reducing ammonia volatilization from urea fertilizer as the concentration of HA is very high in coal.

\section{MATERIALS AND METHODS}

The soil used in this study was Bekenu series (Typic Paleudults). Soil samples were taken at a depth of $0-15 \mathrm{~cm}$ and the coal was taken from Mukah, Sarawak, Malaysia. Both of these samples were air dried and ground to pass through a $2 \mathrm{~mm}$ sieve.

The HA and FA extraction was carried out by the methods of Stevenson ${ }^{[10]}$ and Susilawati et al. ${ }^{[11]}$ with some modifications. Selected chemical and physical properties of soil, HA, FA and urea were determined using standard procedures. The $\mathrm{pH}$ of soil, urea, HA and FA were determined in a 1:2 soil: Distilled water suspension and $\mathrm{KCl}$ using a glass electrode ${ }^{[12]}$.

Soil and HA organic carbon were determined using the Loss-on-ignition method ${ }^{[13]}$. Soil CEC was determined by leaching $1 \mathrm{M}$ ammonium acetate buffer adjusted to $\mathrm{pH} 7.0$ followed by steam distillation ${ }^{[14]}$. Extraction of exchangeable $\mathrm{K}, \mathrm{Ca}$ and $\mathrm{Mg}$ was done by the double acid method described in $\operatorname{Tan}^{[15]}$. After extraction, the cations were measured using atomic absorption spectrophotometry (AAnalyst 800, Perkin Elmer Instruments, Norwalk, CT).

The soil texture was determined using the hydrometer method. Carboxylic-COOH, phenolic-OH and total acidity of HA and FA were determined using the method described by Inbar et al. ${ }^{[16]}$. Level of humification $\left(\mathrm{E}_{4} / \mathrm{E}_{6}\right)$ of HA and FA was determined by spectroscopy ${ }^{[10]}$. The $\mathrm{E}_{4} / \mathrm{E}_{6}$ was determined at wavelengths of 465 and $665 \mathrm{~nm}$.

The 5 treatments evaluated in this study were:

- $\quad$ Soil alone [T0]

- $2.02 \mathrm{~g}$ urea without additives [T1]

- $2.02 \mathrm{~g}$ Urea $+0.75 \mathrm{~g} \mathrm{HA}$ [T2]

- $2.02 \mathrm{~g}$ Urea $+66 \mathrm{~mL}$ of FA $(60 \%$ of soil field capacity) [T3]

- $\quad 2.02$ g Urea + 0.75 g HA + 66 mL FA (60\% of soil field capacity) [T4]

These HA and FA rates were adopted because they gave better mixtures (based on several trials). In addition, studies have shown that less than $1 \mathrm{~g} \mathrm{HA} \mathrm{kg}^{-1}$ soil is sufficient to condition soils ${ }^{[17]}$. The treatments were prepared by first weighing (for each treatment) separately into plastic vials, then tightly closed and shaken on a reciprocal shaker at $150 \mathrm{rpm}$ for $30 \mathrm{~min}$ to ensure thorough mixing.

Daily ammonia loss from soil was measured by a modified closed-dynamic air flow system method ${ }^{[4,18,19]}$. The system comprised of an exchange chamber and a trap (250 $\mathrm{mL}$ Erlenmeyer flask), both stoppered and fitted with an inlet/outlet. The inlet of the chamber was connected to an air pump and the outlet was connected by polyethylene tubing to the trap containing boric acid solution. Soil $(250 \mathrm{~g})$ was placed in the exchange chamber and moistened to and maintained at $60 \%$ field capacity during the experiment.

The treatments were applied to the soil surface. Air was passed through the chambers at a rate of $3.5 \mathrm{~L}^{-1}$ min $^{-1}$ chamber ${ }^{-1}$ and the released of $\mathrm{NH}_{3}$ was captured in the trapping solution containing $75 \mathrm{~mL}$ boric acid, bromocresol green and methyl red indicator. This rate of air flow, corresponding to 8.5 volume exchanges $\min ^{-1}$, was maintained throughout the incubation period using a Gilmont flow meter (Gilmont Instrument, Great Neck, New York) to measure and adjust the air flow. The incubation chambers were maintained at room temperature. Boric acid indicator traps were replaced every $24 \mathrm{~h}$ and back titrated with $0.01 \mathrm{~N} \mathrm{HCl}$, to estimate the $\mathrm{NH}_{3}$ released. Measurement was continued until the loss declined to $1 \%$ of the $\mathrm{N}$ added in the urea ${ }^{[4,18,19]}$. After the incubation period, soil samples were taken at 0 1.5 and 1.5-3.0 cm depth followed by $\mathrm{pH}$, exchangeable $\mathrm{NH}_{4}^{+}, \mathrm{Ca}^{2+}, \mathrm{Mg}^{2+}$ and $\mathrm{K}^{+}$and available $\mathrm{NO}_{3}^{-}$ determination. Exchangeable $\mathrm{NH}_{4}^{+}$and available $\mathrm{NO}_{3}^{-}$ were extracted from the soil by the method of Keeney and Nelson ${ }^{[20]}$. Exchangeable $\mathrm{Ca}^{2+}, \mathrm{Mg}^{2+}$ and $\mathrm{K}^{+}$were extracted by the double acid method ${ }^{[15]}$ and the extracts were analyzed as described previously. 
The experimental design was completely randomized with three replicates for each treatment. Analysis of variance (ANOVA) was used to test treatment effects while means of treatments were compared using Tukey's test ${ }^{[21]}$.

\section{RESULTS}

The soil used in this study was slightly acidic, in both water and $\mathrm{KCl}$ (Table 1). The $\mathrm{CEC}$, exchangeable $\mathrm{K}^{+}$and soil texture were consistent with those reported for Bekenu series by Paramananthan ${ }^{[22]}$. However, $\mathrm{pH}$, total organic carbon and exchangeable $\mathrm{Ca}^{2+}, \mathrm{Mg}^{2+}$ and $\mathrm{Na}^{+}$in this study were contrary to the findings of Paramananthan ${ }^{[22]}$ as they were higher than the reported values.

The selected chemical properties of HA are presented in Table 2. The range of the organic carbon content was consistent with that of $\operatorname{Tan}^{[5]}$. The phenolic-OH, carboxylic- $\mathrm{COOH}$ and total acidity range were also comparable with those reported by Schnitzer ${ }^{[23]}$ and $\operatorname{Tan}^{[5]}$ whereas the $\mathrm{E}_{4} / \mathrm{E}_{6}$ ratios (level of humification of HA) of the HA were similar to those reported by $\operatorname{Tan}^{[5]}$.

The average yield of HA was $3.92 \%$ with the highest being $5.00 \%$ while the lowest was $3.00 \%$. In comparison with leornardite which contains an average of $80 \%$ of $\mathrm{HA}^{[6]}$, the content of $\mathrm{HA}$ in this indigenous coal was very low. A similar study was reported by Fong et al. ${ }^{[24]}$ using coal from Mukah, Sarawak yielding as much as $9.83 \%$ of HA. Conversely, the yield of FA was generally much higher than HA. This is because the FA was not purified during the extraction and fractionation processes as it still contained substantial amounts of $\mathrm{NaOH}$ and $\mathrm{HCl}$.

The $\mathrm{NH}_{3}$ loss started on the second day of incubation for all treatments except for $\mathrm{T} 1$ where the occurrence was on the first day (Fig. 1). The former observation was similar to the study of Ahmed et al ${ }^{[4,25]}$.

Table 1: Physico-chemical characteristics of bekenu series

\begin{tabular}{|c|c|c|}
\hline Property & $\begin{array}{l}\text { Value } \\
\text { obtained }\end{array}$ & $\begin{array}{l}\text { Standard } \\
\text { data range* }\end{array}$ \\
\hline$\overline{\mathrm{pH}_{\mathrm{w}}}$ & 6.90 & $4.60 *$ \\
\hline $\mathrm{pH}_{\mathrm{KCl}}$ & 6.15 & $3.80 *$ \\
\hline Exchangeable $\mathrm{K}^{+}\left(\mathrm{cmol} \mathrm{kg}^{-1}\right)$ & 0.39 & $0.19 *$ \\
\hline Exchangeable $\mathrm{Ca}^{2+}\left(\mathrm{cmol} \mathrm{kg}^{-1}\right)$ & 28.60 & $0.01 *$ \\
\hline Exchangeable $\mathrm{Mg}^{2+}\left(\mathrm{cmol} \mathrm{kg}^{-1}\right)$ & 2.25 & $0.21 *$ \\
\hline Exchangeable $\mathrm{Na}^{+}\left(\mathrm{cmol} \mathrm{kg}^{-1}\right)$ & 2.02 & $0.01 *$ \\
\hline $\mathrm{CEC}\left(\mathrm{cmol} \mathrm{kg}^{-1}\right)$ & 11.41 & $8.0-24 *$ \\
\hline Total organic carbon $(\%)$ & 4.27 & $2.51 *$ \\
\hline Soil texture & SCL & SCL* \\
\hline
\end{tabular}

However, the maximum loss for $\mathrm{T} 1$ and $\mathrm{T} 2$ occurred after two days of incubation while those of T3 and T4 occurred three days after incubation. The latter observation was similar to Ahmed et al. ${ }^{[25]}$ but contradicted that of Ahmed et al. ${ }^{[19]}$ where the maximum loss for the treatments occurred on the fourth day of incubation.

The maximum loss of $\mathrm{NH}_{3}$ during the third day of incubation for T3 and T4 was effectively reduced to half as compared to T1 (urea without additives) where there was a sharp decrease of $\mathrm{NH}_{3}$ loss from $6.7 \%$ for the maximum $\mathrm{NH}_{3}$ loss for $\mathrm{T} 1$ to 3.42 and $3.13 \%$ for $\mathrm{T} 3$ and $\mathrm{T} 4$ respectively. The maximum loss for $\mathrm{T} 2$ was $6.34 \%$.

The total amount of $\mathrm{NH}_{3}$ lost at the end of the study is shown in Table 3. All the treatments with HA and FA (T2, T3 and T4) significantly reduced $\mathrm{NH}_{3}$ loss compared to urea alone (T1). Nonetheless, T4 was more pronounced in reducing $\mathrm{NH}_{3}$ loss compared to other treatments. As a result, the total $\mathrm{NH}_{3}$ loss was effectively reduced to $24.7 \%$ compared to the total loss in T1 (Table 3).

Table 3: Total $\mathrm{NH}_{3}$ loss over 16 days of incubation and the reduction in $\mathrm{NH}_{3}$ loss in comparison with the loss in $\mathrm{T} 1$ (urea without additives)

\begin{tabular}{lll}
\hline Treatment & $\begin{array}{l}\text { Ammonia loss } \\
\text { (\% of urea-N) }\end{array}$ & $\begin{array}{l}\text { Reduction in total } \mathrm{NH}_{3} \text { lost } \\
\text { as compared to T1 }(\%)\end{array}$ \\
\hline T0 & $0.16^{\mathrm{a}}$ & None \\
T1 & $28.13^{\mathrm{b}}$ & None \\
T2 & $24.36^{\mathrm{c}}$ & 13.39 \\
T3 & $23.16^{\mathrm{c}}$ & 17.67 \\
T4 & $21.18^{\mathrm{d}}$ & 24.70 \\
\hline
\end{tabular}

Note: Mean values with different letters are significantly different between treatments at $\mathrm{p} \leq 0.05$ using Tukey's test

Table 2: Comparison of selected chemical properties of HA isolated from coal with related reports

\begin{tabular}{lll}
\hline Property & HA, Present study & Ha, Reference \\
\hline pH (water) & $1.89-2.27$ & \\
pH (2 M KCl) & $1.54-1.86$ & \\
Total organic carbon $(\%)$ & $53.36-53.94$ & $48.90-58.50 * *$ \\
Phenolic group $\left(\mathrm{cmol} \mathrm{kg}^{-1}\right)$ & $350-400$ & $150-440^{*}$ \\
Carboxylic group $\left(\mathrm{cmol} \mathrm{kg}^{-1}\right)$ & $500-575$ & $240-540^{* *}$ \\
Total acidity $\left(\mathrm{cmol} \mathrm{kg}^{-1}\right)$ & $850-970$ & $570-890^{*}$ \\
& & $390-980^{* *}$ \\
E4/E6 & $4.04-4.37$ & $3.3-5.0^{* *}$ \\
& & $7-8$ or higher** \\
\hline
\end{tabular}

Source: *: Schnitzer ${ }^{[23]}$ and $* *: \operatorname{Tan}^{[5]}$

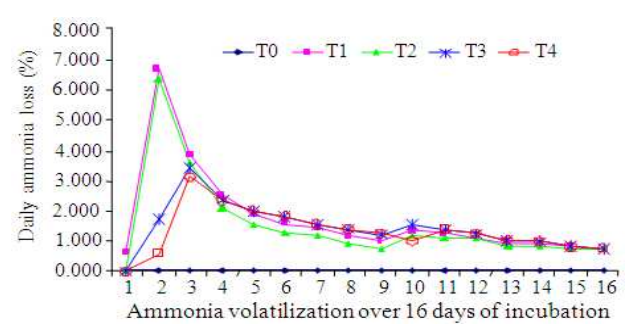

Fig. 1: Daily ammonia loss for treatments throughout 16 days of incubation 


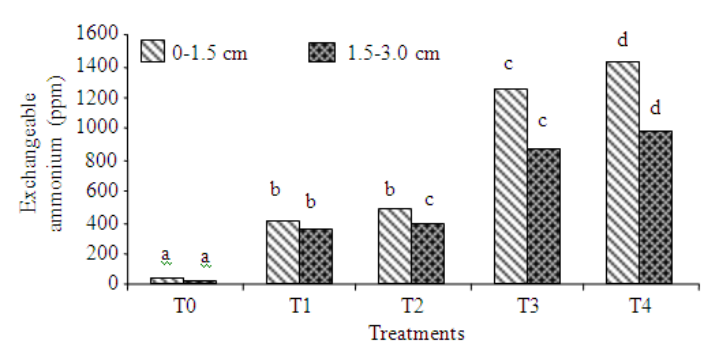

Fig. 2: Effects of treatments on ammonium accumulation after 16 days of incubation

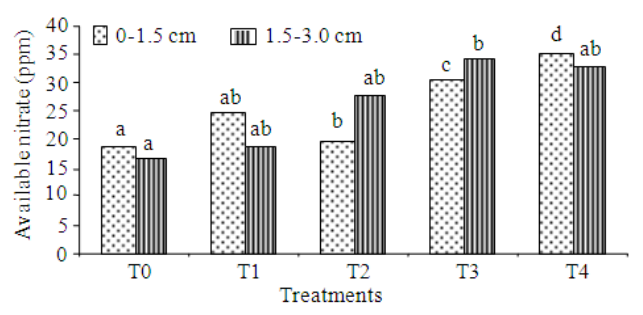

Fig. 3: Effects of treatments on available nitrate after 16 days of incubation

There was no significant difference between $\mathrm{T} 1$ and $\mathrm{T} 2$ in the accumulation of $\mathrm{NH}_{4}{ }^{+}$for both depths. However, there was substantial accumulation of $\mathrm{NH}_{4}{ }^{+}$ for T3 and T4 respectively at $0-1.5 \mathrm{~cm}$ compared to $\mathrm{T} 1$ (Fig. 2).

Significant accumulation of available $\mathrm{NO}_{3}{ }^{-}$for $\mathrm{T} 3$ and T4 was observed in contrast with other treatments; T0, T1 and T2 respectively at 0-1.5 cm depth (Fig. 3). This finding is consistent with Ahmed et al ${ }^{[4]}$ and Fan and Mackenzie ${ }^{[26]}$ who reported significant accumulation of $\mathrm{NO}_{3}{ }^{-}$compared to the control treatment but contrary to the study of Ahmed et al ${ }^{[19,25]}$. However, there was no significant difference in the amount of accumulated $\mathrm{NO}_{3}{ }^{-}$ for T0 and T1 for both soil depths.

For exchangeable cations, there were no significant differences between $\mathrm{T} 0, \mathrm{~T} 1$ and $\mathrm{T} 2$ regardless of depth, However, T3 and T4 were statistically different from T0, T1 and T2 at both depths except for exchangeable $\mathrm{K}$ at $1.5-3 \mathrm{~cm}$ depth, where $\mathrm{T} 4$ showed no significant difference from $\mathrm{T} 0, \mathrm{~T} 1$ and $\mathrm{T} 2$.

At 1.5-3.0 cm depth, T3 showed the highest accumulation of all exchangeable cations followed by T2 (Table 4). The increment was attributed to the fact that FA was not purified, containing high amounts of $\mathrm{NaOH}$ from the extraction process. The lowest accumulation of exchangeable cations occurred for T4. This finding contradicts the study of Ahmed et al. ${ }^{[4,19]}$ which could be because of the different sources of HA and FA used.
Table 4: Soil exchangeable $\mathrm{K}, \mathrm{Ca}, \mathrm{Mg}$ and $\mathrm{Na}$ at $0-1.5$ and $1.5-3.0 \mathrm{~cm}$ after 16 days of incubation

\begin{tabular}{|c|c|c|c|c|c|c|c|c|}
\hline \multirow[b]{3}{*}{ Treatment } & \multicolumn{8}{|c|}{ Exchangeable cations (c moL kg${ }^{-1}$ ) } \\
\hline & \multirow[b]{2}{*}{$\mathrm{K}$} & \multicolumn{3}{|c|}{$0-1.5 \mathrm{~cm}$} & \multicolumn{4}{|c|}{$1.5-3.0 \mathrm{~cm}$} \\
\hline & & $\mathrm{Ca}$ & $\mathrm{Mg}$ & $\mathrm{Na}$ & K & $\mathrm{Ca}$ & $\mathrm{Mg}$ & $\mathrm{Na}$ \\
\hline $\mathrm{T} 0$ & $0.38 \mathrm{a}$ & $25.07 \mathrm{~b}$ & $1.96 \mathrm{bc}$ & $1.05 \mathrm{a}$ & $0.58 \mathrm{a}$ & $32.52 \mathrm{~b}$ & $2.39 \mathrm{~b}$ & $0.34 \mathrm{~b}$ \\
\hline $\mathrm{T} 1$ & $0.41 \mathrm{a}$ & $29.29 \mathrm{~b}$ & $2.12 \mathrm{c}$ & $0.29 \mathrm{a}$ & $0.64 \mathrm{a}$ & $30.05 \mathrm{~b}$ & $2.19 \mathrm{~b}$ & $0.28 \mathrm{~b}$ \\
\hline $\mathrm{T} 2$ & $0.58 \mathrm{a}$ & $29.51 \mathrm{~b}$ & $2.18 \mathrm{c}$ & $0.64 \mathrm{a}$ & $0.45 \mathrm{a}$ & $29.37 \mathrm{~b}$ & $2.21 \mathrm{~b}$ & $0.57 \mathrm{~b}$ \\
\hline T3 & $1.14 \mathrm{~b}$ & $15.97 \mathrm{a}$ & $1.52 \mathrm{ab}$ & $16.91 \mathrm{~b}$ & $1.68 \mathrm{~b}$ & $50.20 \mathrm{a}$ & $3.60 \mathrm{c}$ & $19.7 \mathrm{c}$ \\
\hline $\mathrm{T} 4$ & $1.26 \mathrm{~b}$ & $12.70 \mathrm{a}$ & $1.44 \mathrm{a}$ & $18.22 \mathrm{c}$ & $0.13 a$ & $1.38 \mathrm{c}$ & $0.32 \mathrm{a}$ & $0.11 \mathrm{a}$ \\
\hline
\end{tabular}

Table 5: $\mathrm{pH}$ of air-dried soil after 16 days of incubation

\begin{tabular}{lllll}
\hline & $\mathrm{pH}$ (water) & & $\mathrm{pH}(2 \mathrm{M} \mathrm{KCl})$ \\
& - & & - \\
Treatments & $0-1.5 \mathrm{~cm}$ & $1.5-3.0 \mathrm{~cm}$ & $0-1.5 \mathrm{~cm}$ & $1.5-3.0 \mathrm{~cm}$ \\
\hline T0 & $6.81 \mathrm{a}$ & $7.23 \mathrm{a}$ & $6.13 \mathrm{a}$ & $6.26 \mathrm{a}$ \\
$\mathrm{T} 1$ & $8.15 \mathrm{c}$ & $8.02 \mathrm{a}$ & $7.46 \mathrm{~b}$ & $7.53 \mathrm{~b}$ \\
$\mathrm{~T} 2$ & $8.15 \mathrm{c}$ & $7.96 \mathrm{a}$ & $7.49 \mathrm{~b}$ & $7.49 \mathrm{~b}$ \\
$\mathrm{~T} 3$ & $7.08 \mathrm{~b}$ & $7.58 \mathrm{a}$ & $6.81 \mathrm{c}$ & $7.56 \mathrm{~b}$ \\
$\mathrm{~T} 4$ & $6.97 \mathrm{ab}$ & $7.56 \mathrm{a}$ & $6.44 \mathrm{~d}$ & $7.54 \mathrm{~b}$ \\
\hline
\end{tabular}

Note: Mean values with different letters (within column) are significantly different between treatments at $\mathrm{p} \leq 0.05$ using Tukey's test

The $\mathrm{pH}$ (water and $\mathrm{KCl}$ ) at $0-1.5 \mathrm{~cm}$ of the treatments with urea mixtures were significantly different from the control (T0) except for T4 which was not significantly different from $\mathrm{T} 0$ for $\mathrm{pH}$ in water. However, no such differences were observed for all the treatments at 1.5-3 cm depth for $\mathrm{pH}$ in water (Table 5).

Conversely, this was not true for $\mathrm{pH}$ in $\mathrm{KCl}$ at the same depth where all of the treatments with urea additives were significantly different from T0. It was also found that the $\mathrm{pH}$ for $\mathrm{T} 1$ and $\mathrm{T} 2$ were not statistically different regardless of depth and medium used for the $\mathrm{pH}$ determination. Treatment with the highest amount of mixture particularly $\mathrm{T} 4$ gave the lowest $\mathrm{pH}$ throughout the study as it contained both HA and FA that had very low initial $\mathrm{pH}$.

\section{DISCUSSION}

The high $\mathrm{pH}$, total organic carbon, exchangeable $\mathrm{Ca}, \mathrm{Mg}$ and $\mathrm{Na}$ in this study could be attributed to the adulteration of the soil in previous years. It was found that exchangeable $\mathrm{Ca}$ was substantially higher than the reported values.

This result suggests that liming activities had probably been carried out in the area, thus causing the differences in the selected chemical properties of the soil. According to Havlin et al. ${ }^{[27]}$, liming raises soil $\mathrm{pH}$ which in turn affects the CEC of the soil. As $\mathrm{pH}$ increases, it will result in an increase in effective CEC, consequently increasing the availability of basic cations 
such as $\mathrm{K}^{+}, \mathrm{Mg}^{2+}$ and $\mathrm{Na}^{+}$. As $\mathrm{pH}$ increases, more microorganisms are able to thrive in the soil and are able to actively breakdown organic materials in the soil, therefore increasing the total organic carbon in the soil.

The effectiveness of washing HA with distilled water is supported by the fact that the ranges of the phenolic-OH, carboxylic-COOH and total acidity of the HA were found to be within the ranges reported by other authors as previously mentioned in Table 2 . Studies by Chen et al. ${ }^{[28]}$ revealed that a low $\mathrm{E}_{4} / \mathrm{E}_{6}$ ratio is associated with a relatively large molecular size or high molecular weight. This molecule has high carbon content, but is relatively low in oxygen $(\mathrm{O})$, carboxylic $(\mathrm{COOH})$ group and total acidity. On the other hand, several studies have shown that FA has relatively low molecular weights as compared to HA but has higher oxygen and lower carbon contents than the high molecular weight HA. FA was also found to contain more functional groups of an acidic nature, particularly $\mathrm{COOH}^{[5,29]}$.

The type of coal used in this study was subbituminous, which ranked higher than lignite coals due to its higher combustible energy, thus higher carbon content. It was also found that the carbon content of the coal used in this study ranged between 38.6-43.5\%, typical of those reported for sub-bituminous coal, ranging between $35-45 \%$ of carbon. The low yields of HA could be attributed to increasing coalification (from lignite, sub bituminous, bituminous to anthracite coal), where the material is more likely to become less extractable with dilute alkali solutions ${ }^{[30]}$.

The literature on high yield of $\mathrm{HA}$ is predominantly focus on lignite coals. Stevenson ${ }^{[29]}$, Lobartini et $a l .{ }^{[7]}$ and Tan and Rema ${ }^{[8,9]}$ agreed that lignite coals contain about $99.5 \%$ HA. Mayhew ${ }^{[6]}$ has also reported high content of HA in leonardite (lignite in North Dakota) with an average yield of $80 \%$. However, this was not found in sub-bituminous coals as they contain less HA and $\mathrm{FA}^{[30]}$.

All of the treatments with additives indicated significant reduction in ammonia volatilization compared to urea alone (T1). This reduction may be attributed to low pH of HA (1.89-2.27) and FA (1.141.20 ) added to the urea, causing a temporary reduction in $\mathrm{pH}$ of the soil therefore causing a delay in urea hydrolysis. The high loss of $\mathrm{NH}_{3}$ for $\mathrm{T} 1$ was most likely due to the high initial $\mathrm{pH}$ of the soil that accelerated the hydrolysis of urea. Since the unpurified FA was more acidic, the formation of more $\mathrm{NH}_{4}{ }^{+}$over $\mathrm{NH}_{3}$ was possible. This explains the sharp reduction in $\mathrm{NH}_{3}$ loss in day 3 for T3 and T4 (Fig. 1).

Apart from having low $\mathrm{pH}$, the total acidity of HA and FA were also high. As urea hydrolyses, it releases large amounts of $\mathrm{NH}_{4}^{+}$into the soil solution together with $\mathrm{HCO}_{3}{ }^{-}$. This positively charged $\mathrm{NH}_{4}{ }^{+}$is in turn adsorbed to the negatively charged sites of phenolic$\mathrm{OH}$ and carboxylic-COOH compounds of HA and FA. As a result, the concentration of ammoniacal $\mathrm{N}$ in the soil solution at any one time which is subject to volatilization is reduced.

The $\mathrm{NH}_{4}^{+}$and $\mathrm{NO}_{3}^{-}$accumulation increased significantly in the soils treated with HA and FA at 0$1.5 \mathrm{~cm}$ and $1.5-3.0 \mathrm{~cm}$ depth respectively as this was attributed to the added HA and FA that contained high amounts of phenolic-OH and carboxylic-COOH compounds which were able to capture and retain $\mathrm{NH}_{4}{ }^{+}$ from being transformed to $\mathrm{NH}_{3}$. However, there was no significant accumulation of $\mathrm{NH}_{4}^{+}$for $\mathrm{T} 2$ (urea $+\mathrm{HA}$ ) compared to T1 (urea only). This was most probably due to the high soil $\mathrm{pH}$ after the mixtures had been applied ( $\mathrm{pH} 8.15$ in water). This observation is buttressed by previous findings of Siva et al. ${ }^{[18]}$ who stated that HA is more pronounced in reducing $\mathrm{NH}_{3}$ volatilization subsequently capturing and retaining $\mathrm{NH}_{4}{ }^{+}$in acidic soils where the $\mathrm{pH}$ is low. This was again supported by the observation for T3 (urea + FA) and T4 (urea + HA + FA) which showed that when FA is applied to the soil, it acidifies the soil (attributed to the large amounts of $\mathrm{HCl}$ in the unpurified FA solution) thus reducing the $\mathrm{pH}$ of the soil which provides conditions for effective capturing and retention of $\mathrm{NH}_{4}{ }^{+}$ in the soil.

The high accumulation of $\mathrm{NO}_{3}{ }^{-}$in the treated soil could be attributed to the high amounts of $\mathrm{Ca}^{2+}$ in the soil as well as a high soil $\mathrm{pH}$ which are suitable for a broad spectrum of microorganisms responsible for the transformation of $\mathrm{NH}_{4}{ }^{+}$to $\mathrm{NO}_{3}{ }^{-}$. According to Havlin et al. ${ }^{[27]}$, most of the organisms responsible for the conversion of $\mathrm{NH}_{4}{ }^{+}$to $\mathrm{NO}_{3}{ }^{-}$require adequate supply of $\mathrm{Ca}^{2+}$. The content of exchangeable $\mathrm{Ca}$ (Table 4) decreased from T1 to T4. This shows that $\mathrm{Ca}^{2+}$ ions were utilized by the microorganisms to convert $\mathrm{NH}_{4}{ }^{+}$to $\mathrm{NO}_{3}{ }^{-}$.

The high soil pH for T1 and T2 (Table 5) regardless of depth partly explains the insignificant difference in the concentrations of the exchangeable cations of the two treatments. According to Havlin et al. ${ }^{[27]}$, the availability of the macronutrients particularly exchangeable cations such as $\mathrm{K}^{+}, \mathrm{Ca}^{2+}, \mathrm{Mg}^{2+}$ and $\mathrm{Na}^{+}$decreases with increased $\mathrm{pH}$.

The increase in the concentration of $\mathrm{Na}^{+}$from $\mathrm{T} 2$ to T4 may be attributed to the $\mathrm{Na}^{+}$ions in the $\mathrm{NaOH}$ solution used during the extraction process. However, at $1.5-3.0 \mathrm{~cm}$ depth, the soil treated with $\mathrm{T} 3 \mathrm{had}$ the highest amount of exchangeable cations while T4 was found to contain the lowest amount of exchangeable 
cations. This difference can be explained based on the fact that the presence of HA and FA in T4 might have improved the soil's exchangeable cation retention ability at $0-1.5 \mathrm{~cm}$. This also suggests the effectiveness of $\mathrm{HA}$ and FA in improving exchangeable cation retention at $0-1.5 \mathrm{~cm}$ only.

The result in Table 5 show decreasing $\mathrm{pH}$ values from T1-T4 at 0-1.5 cm depth for both $\mathrm{pH}$ determinants (water and $\mathrm{KCl}$ solution). This is typical for $\mathrm{HA}$ and FA as the $\mathrm{pH}$ of FA was much lower than HA due to the presence of $\mathrm{HCl}$ in the unpurified $\mathrm{FA}$ solution. Therefore the $\mathrm{pH}$ of $\mathrm{T} 3$ (urea $+\mathrm{FA}$ ) was lower than T2 (urea + HA). However, T4 had the lowest $\mathrm{pH}$ value which was attributed to the presence of both HA and FA. The reduction in $\mathrm{pH}$ effectively reduced ammonia volatilization, increased $\mathrm{NH}_{4}{ }^{+}$retention and other exchangeable cations. The loss of $\mathrm{NH}_{3}$ from urea without additives was possibly due to the increased alkalinity due to urea hydrolysis, $(\mathrm{pH}$ of 8.15 in water after treatment application) hence exceeding the localized buffering capacity of the soil or its retention capacity for $\mathrm{NH}_{4}{ }^{+}$.

\section{CONCLUSION}

Amending urea with HA and FA may offer a significant advantage over urea without additives by increasing the formation of $\mathrm{NH}_{4}{ }^{+}$over $\mathrm{NH}_{3}$ while retaining more of the cations within the soil. Reducing $\mathrm{NH}_{3}$ volatilization from urea may also contribute to the reduction of environmental pollution from excessive utilization of $\mathrm{N}$ fertilizers. It must be stressed that the results obtained in the volatilization experiment using a slightly acidic (pH 6.13-6.9) soil may only be applicable to similar type of soils.

The effectiveness of this study may be improved by using lignite coals that can yield higher amounts of HA instead of using sub-bituminous coals.

\section{ACKNOWLEDGEMENT}

The researchers acknowledge the financial support of this research by the Ministry of Higher Education, Malaysia.

\section{REFERENCES}

1. Anonymous, 2006. International fertilizer industry association. International Fertilizer Industry Association.

http://www.linkedin.com/companies/internationalfertilizer-industry-association-ifa
2. Bundy, L.G., T.W. Andraski and T.C. Daniel, 1992. Placement and timing of nitrogen fertilizers for conventional and conservation tillage corn production. J. Prod. Agric., 5: 214-221. http://cat.inist.fr/?aModele=afficheN\&cpsidt=5228159

3. Jones, C.A., R.T. Koenig, J.W. Ellsworth, B.D. Brown and G.D. Jackson, 2007. Management of urea fertilizer to minimize volatilization. EB 173. Montana State University Extension Service. Bozeman, Montana.

https://www.certifiedcropadviser.org/certified/educ ation/self-study/exam_pdf/109.pdf

4. Ahmed, O.H., H. Aminuddin and M.H.A. Husni. 2006. Effects of urea, humic acid and phosphate interactions in fertilizer microsites on ammonia volatilization and soil ammonium and nitrate contents. Int. J. Agric. Res., 1: 25-31. DOI: 10.3923/ijar.2006.25.31

5. Tan, K.H., 2003. Humic Matter in Soil and the Environment: Principles and Controversies. Marcel Dekker, Inc., New York, ISBN: 0824742729, pp: 386.

6. Mayhew, L., 2004. Humic substances in biological agriculture. ACRES USA. http://www.acresusa.com/toolbox/reprints/Jan04_H umic\%20Substances.pdf

7. Lobartini, J.C., K.H. Tan, J.A. Rema, A.R. Gingle, C. Pape and D.S. Himmelsbach, 1992. The geochemical nature and agricultural importance of commercial humic matter. Sci. Total Environ., 113: 1-15.

http://cat.inist.fr/?aModele=afficheN\&cpsidt=5319241

8. Stevenson, F.J., 1994. Humus Chemistry, Genesis, Composition, Reactions. 2nd Edn., John Wiley and Sons, Inc., New York, ISBN: 0471594741, pp: 496.

9. Susilawati, K., O.H. Ahmed, A.B. Nik Muhamad and M.Y. Khanif, 2007. Effects of extraction and fractionation period on the yield of a tropical peat soil (hemists) humic acids. Am. J. Agric. Biol. Sci., 2: 202-205.

http://www.scipub.org/fulltext/AJAB/AJAB23202205.pdf

10. Chefetz, B., P.H. Hatcher, Y. Hadar and Y. Chen, 1996. Chemical and biological characterization of organic matter during composting of municipal solid waste. J. Environ. Q., 25: 776-785. http://jeq.scijournals.org/cgi/reprint/25/4/776.

11. Tan, K.H., 1996. Soil Sampling, Preparation and Analysis. New York, Marcel Dekker, Inc., ISBN: 0824796756, pp: 408.

12. Inbar, Y., Y. Chen and Y. Hardar, 1990. Humic substances formed during the compositing of organic matter. Soil Sci. Soc. Am. J., 54: 1316-1323. http://soil.scijournals.org/cgi/reprint/54/5/1316. 
13. Piccolo, A., 1996. Humus and Soil Conservation. In: Humic Substances in Terrestrial Ecosystems, Piccolo, A. (Eds.). Amsterdam, Elsevier Science B.V., ISBN: 978-0-444-81516-3, pp: 225-264.

14. Siva, K.B., H. Aminuddin, M.H.A. Husni and A.R. Manas, 1999. Ammonia volatilization from urea as affected by tropical-based palm oil palm effluent (pome) and peat. Comm. Soil Sci. Plant Anal., 30: 785-804. DOI: 10.1080/00103629909370246

15. Ahmed, O.H., H. Aminuddin and M.H.A. Husni, 2006. Reducing ammonia loss from urea and improving soil-exchangeable ammonium retention through mixing triple superphosphate, humic acid and zeolite. Soil Use Manage., 22: 315-319. DOI: 10.1111/j.1475-2743.2006.00040.x

16. Keeney, D.R. and D.W. Nelson, 1982. NitrogenInorganic Forms. In: Methods of Soil Analysis: Part 2, Keeney, D.R.D.E., R.H. Baker, R. Miller, J. Elis, A.L. Page and J.D. Rhodes (Eds.). 2nd Edn., Agron. Monogr. 9; ASA and SSSA, Madison, WI., USA. ISBN: 0891180729.

17. SAS., 2001. SAS/STAT Software. SAS Institute, Cary, NC., ISBN: 1580258506, pp: 352.

18. Paramananthan, S., 2000. Soils of Malaysia: Their Characteristics and Identification. Academy of Sciences Malaysia, Kuala Lumpur, ISBN: 9839445-06-5.

19. Schnitzer, M., 1978. Humic Substances: Chemistry and Reactions. In: Soil Organic Matter, Schnitzer, M. and S.U. Khan (Eds.). Elsevier Science Publishing Company Inc., New York, USA., ISBN: 0444416102, pp: 1-58.

20. Fong, S.S., L. Seng, W.N. Chong, J. Asing, M.F.M. Nor and A.S.M. Pauzan, 2006. Characterization of the coal derived humic acids from Mukah, Sarawak as soil conditioner. J. Braz. Chem. Soc., 17: 582-587. DOI: 10.1590/S010350532006000300023
21. Ahmed, O.H., H. Aminuddin and M.H.A. Husni, 2008. Ammonia volatilization and ammonium accumulation from urea mixed with zeolite and triple superphosphate. Acta Agric. Scandinavica Section B-Soil and Plant Sci., 58: 182-186. DOI: 10.1080/09064710701478271.

22. Fan, M.X. and A.F. Mackenzie, 1993. Urea and phosphate interactions in fertilizer microsites: Ammonia volatilization and $\mathrm{pH}$ changes. Soil Sci. Soc. Am. J., 57: 839-845. http://soil.scijournals.org/cgi/reprint/57/3/839

23. Havlin, J.L., T.L. Samuel, W.L. Nelson and J.D. Beaton, 1998. Soil Fertility and Fertilizers: An Introduction to Nutrient Management. 6th Edn., Prentice Hall, Upper Saddle River, New Jersey, ISBN: 10: 0136268064, pp: 499.

24. Chen, Y., N. Senesi and M. Schnitzer, 1977. Information provided on humic substances by $\mathrm{E}_{4} / \mathrm{E}_{6}$ ratios. Soil Sci. Soc. Am. J., 41: 352-358. http://soil.scijournals.org/cgi/reprint/41/2/352

25. Stevenson, F.J., 1982. Humus Chemistry, Genesis, Composition, Reactions. John Wiley and Sons, Inc., New York. ISBN: 0471594741

26. Hatcher, P.G., I.A. Breger, G.E. Macial and N.M. Szeverenyi, 1985. Geochemistry of Humin. In: Humic Substances in Soil, Sediment and Water. Geochemistry, Isolation and Characterization, Aiken, G.R., D.M. Mcknight, R.L. Wershaw and P. MacCarthy (Eds.). Wiley-Interscience, New York, USA., ISBN: 0894646346, pp: 25-302. 